Volume 1, Nomor 2, Maret 2021, hlm 95-102

BEMAS: JURNAL BERMASYARAKAT

p ISSN 27455866 | e ISSN 27457958

\title{
OPTIMALISASI PERAN KADER KESEHATAN DALAM DETEKSI DINI STUNTING
}

\author{
Fayakun Nur Rohmah $^{1 *}$, Siti Arifah ${ }^{2}$ \\ 1* Prodi Sarjana dan Profesi Bidan, Fakultas Ilmu Kesehatan, Universitas 'Aisyiyah Yogyakarta, Jln Siliwangi \\ No 63, Mlangi, Nogotirto, Gamping, Sleman, Yogyakarta \\ ${ }^{2}$ Prodi D3 Kebidanan, Fakultas Ilmu Kesehatan, Universitas 'Aisyiyah Yogyakarta, Jln Siliwangi No 63, \\ Mlangi, Nogotirto, Gamping, Sleman, Yogyakarta \\ Email: *fayakun.nurrohmah@unisayogya.ac.id, sitiarifah@unisayogya.ac.id
}

INFORMASI ARTIKEL

\section{Article History:}

Submission: 04-03-2021

Revised:15-03-2021

Accepted: 18-03-2021

* Korespondensi:

Fayakun Nur Rohmah

fayakun.nurrohmah@unisayogya.ac.id

\begin{abstract}
ABSTRAK
Data Riset Kesehatan Dasar (Riskesdas) 2018 menunjukkan prevalensi stunting di Indonesia sebesar 30,8\% walaupun sudah turun di tahun 2019 menjadi 27,67\% akan tetapi masih memerlukan perhatian yang serius baik dari pemerintah maupun seluruh anggota masyarakat. Posyandu dan puskesmas merupakan garda terdepan dalam upaya pengendalian stunting. Kader Kesehatan adalah mitra bidan dalam pelaksanaan deteksi dini pertumbuhan balita di posyandu dan merupakan enumerator utama dalam pengambilan data Panjang/ tinggi badan, realitanya banyak kader yang belum memiliki pengetahuan baik tentang stunting dan keterampilan yang baik dalam pengukuran Panjang atau tinggi badan. Kegiatan pengabdian masyarakat ini bertujuan untuk meningkatkan pengetahuan tentang stunting dan keterampilan kader dalam melakukan pengukuran Panjang atau tinggi badan balita dengan tepat. Pengabdian masyarakat ini dilaksanakan pada 2 posyandu di Karangkajen, Brontokusuman, Mergangsan, Yogyakarta. Kegiatan utama yang dilaksanakan dalam pengabdian masyarakat ini adalah pelatihan penguatan pengetahuan tentang stunting, pelatihan validasi alat, penggunaan alat dan interpretasi hasil pengukuran Panjang/tinggi badan. Kegiatan dilaksanakan 3 kali pertemuan meliputi kegiatan pelatihan 2 kali pertemuan dan 1 kali pertemuan untuk evaluasi. Kegiatan pengabdian masyarakat terlaksana bulan Juni-Agustus 2020. Hasil kegiatan menunjukkan adanya peningkatan pengetahuan dan praktik kader dalam melakukan pengukuran Panjang/tinggi badan pada balita

Kata Kunci: Stunting, Pelatihan Kader

OPTIMIZING THE ROLE OF HEALTH CADRES IN STUNTING EARLY DETECTION

\begin{tabular}{l} 
ABSTRACT \\
\hline Basic Health Research Data (Riskesdas) 2018 shows the \\
prevalence of stunting in Indonesia by $30.8 \%$ although it has \\
dropped in 2019 to $27.67 \%$ but still requires serious attention from \\
both the government and all members of the public. Posyandu and \\
primary health care are the vanguards in stunting control efforts. \\
Health cadres is a midwife partner in the implementation of early \\
detection of toddler growth in primary health care and is the main \\
enumerator in the collection of long / height data, the reality is that
\end{tabular}
\end{abstract}




\begin{abstract}
many cadres do not have good knowledge about stunting and good skills in measuring length/height. This community service activity aims to increase knowledge about stunting and cadre skills in measuring the length/height of toddlers appropriately. This community service was carried out at 2 posyandu in Karangkajen, Brontokusuman, Mergangsan, Yogyakarta. The main activities carried out in this community service are training on strengthening knowledge about stunting, training on tool validation, use of tools, and interpretation of long/height measurement results. The activity was held 3 meetings including training activities 2 meetings and 1 meeting for evaluation. Community service activities are carried out in June-August 2020. The results of the activity showed an increase in the knowledge and practice of cadres in measuring length/height in toddlers
\end{abstract}

Keywords: Stunting, cadre training

\section{PENDAhULUAN}

Angka prevalensi stunting dan malnutrisi di Indonesia merupakan salah satu yang tertinggi diantara negara di ASEAN, 1 dari 3 anak Indonesia berusia di bawah 5 tahun mengalami stunting[1]. Hasil Riset Kesehatan Dasar (Riskesdas) 2018 menunjukkan prevalensi stunting di Indonesia sebesar 30.8\%. Menurut data Soft Launching Hasil Survei Status Gizi Balita Indonesia (SSGBI) Oktober 2019 prevalensi stunting turun menjadi 27,67\%[2]. Pemerintah menargetkan penurunan angka stunting menjadi 19\% pada tahun 2024 yang dituangkan dalam Rencana Pembangunan Jangka Menengah Nasional (RPJMN) 2020-2024[3]. Menurut Kementrian Kesehatan RI bahwa hasil pengukuran tinggi badan anak balita dibandingkan dengan umurnya dengan nilai z-skornya kurang dari -2SD (Standar Deviasi) disebut pendek pendek dan kurang dari-3 SD disebut sangat pendek[4].

Gangguan pertumbuhan linier atau yang sering disebut sebagai stunting terjadi terutama dalam 23 tahun pertama kehidupan. Hal tersebut merupakan manifestasi dari efek interaksi antara kurangnya asupan energi dan gizi serta kejadian infeksi. Secara teori dijelaskan bahwa pada usia tersebut efek berat badan lahir terhadap stunting terbesar adalah pada usia 6 bulan awal dan akan menurun hingga usia 2 tahun. Selain itu, sanitasi lingkungan yang kurang baik, faktor sosial ekonomi keluarga juga merupakan salah satu faktor risiko kejadian stunting[5]. Terkait dengan faktor demografi ternyata data menunjukkan bahwa stunting terjadi di desa maupun di kota, dan tidak hanya pada masyarakat miskin tetapi juga terjadi pada 29\% kelompok masyarakat kaya[6].

Pemerintah melakukan berbagai upaya untuk meminimalisir dampak stunting yang dapat terjadi sepanjang kehidupan anak. Stunting tidak hanya berpengaruh terhadap kapasitas perkembangan otak anak dalam bidang akademik dan produktivitas ekonomi, akan tetapi juga meningkatkan resiko terhadap penyakit kronis saat dewasa. Sehingga, stunting merupakan ancaman bagi masa depan generasi muda dan bangsa yang harus mendapatkan perhatian khusus oleh pemerintah dan seluruh masyarakat[7]. Salah satu program pemerintah dalam upaya melakukan pencegahan dan screening terhadap kejadian stunting adalah dengan pemanfaatan posyandu balita. Posyandu merupakan salah satu bentuk Upaya Kesehatan Bersumber Daya Masyarakat (UKBM) yang dikelola dan diselenggarakan dari, oleh, untuk dan bersama masyarakat dalam penyelenggaraan pembangunan Kesehatan.

Program ini bertujuan untuk pemberdayaan masyarakat dan memperluas jangkauan pelayanan kesehatan dasar untuk percepatan penurunan angka kematian ibu dan bayi[8]. Posyandu balita berperan besar dalam stimulasi, deteksi dini dan intervensi dini pada tumbuh kembang anak balita melalui penimbangan dan pengukuran tinggi badan anak, bahkan posyandu dan puskesmas merupakan garda terdepan dalam pengendalian stunting[9][10]. Kader kesehatan memiliki jalur komunikasi yg terdekat 
dengan masyarakat, karena merupakan mitra bidan dalam pelaksanaan pemantauan tumbuh kembang anak melalui posyandu. Bahkan kader merupakan enumerator dalam pengumpulan data pemeriksaan panjang/tinggi badan balita, akan tetapi banyak kader belum memahami dengan benar bagaimana cara mengidentifikasi anak stunting[6][11].

Pengetahuan kader kesehatan berkaitan dengan akurasi pengukuran yang dilakukan. Ditunjukkan dalam penelitian bahwa sebanyak 91,1\% kader dengan pengetahuan yang baik memiliki tingkat presisi yang baik juga sedangkan kader yang memiliki pengetahuan yang kurang hanya 35\% kader yang tingkat presisinya yang baik[12]. Kesalahan hasil pengukuran kader umumnya berkaitan dengan keterampilan kader yang tidak cukup, kesalahan alat dan kesulitan saat melakukan pengukuran[13].

Berdasarkan hasil observasi pada posyandu mitra, tidak semua kader kesehatan memiliki pemahaman yang baik tentang stunting. Didapatkan beberapa hal yang kurang tepat dalam pelaksanaan pengukuran Panjang/Tinggi badan anak diantaranya:

a. Belum memiliki alat standar yang digunakan dalam melakukan pengukuran panjang badan

b. Pemasangan alat yang kurang tepat.

c. Teknik pengukuran yang kurang tepat seperti cara memposisikan anak, cara membaca hasil dan melakukan koreksi terhadap hasil pengukuran.

Kegiatan pengabdian kepada masyarakat ini bertujuan untuk meningkatkan pengetahuan dan keterampilan kader sehingga hasil pengukuran data stunting tepat.

\section{METODE}

Pengabdian masyarakat ini dilaksanakan dalam waktu 3 bulan di 2 Posyandu di Karangkajen, Brontokusuman, Mergangsan, Yogyakarta dengan rancangan kegiatan sebagai berikut:

a. Konsolidasi: Kegiatan ini diawali dengan koordinasi dengan dukuh dan kader pada mitra I dan mitra II. Dalam kegiatan ini tim beserta mitra menentukan prioritas permasalahan dan planning of action dalam pengabdian masyarakat ini.

b. Pengadaan alat pengukuran TB dan PB

Tim menyediakan infantometer dan microtoise untuk digunakan dalam pelatihan kader yang digunakan sebagai standar gold pemeriksaan.

c. Penyusunan modul pelatihan.

d. Pelatihan Pemantauan Tumbuh Kembang.

1) Materi 1: Terdiri atas materi pengertian stunting, dampak, faktor yang mempengaruhi stunting, cara pencegahan dan indikator stunting, alat, cara pemeriksaan TB/BB dan Interpretasi data.

2) Materi 2: Praktik pengukuran Panjang/tinggi badan diantaranya Kader dilatih cara memasang dan menyiapkan alat untuk pengukuran Panjang/tinggi badan dengan tepat. Kader akan dilatih melakukan pemeriksaan pengukuran panjang badan dan tinggi badan serta menginterpretasikan data pengukuran panjang badan dan tinggi badan dengan tepat.

Monitoring dan evaluasi: Tim melakukan monitoring dengan melakukan pendampingan saat kader melakukan pengukuran Panjang/ tinggi badan anak pada saat kunjungan rumah karena kondisi pandemi Covid-19 yang menghentikan kegiatan Posyandu.

\section{HASIL DAN PEMBAHASAN}

\subsection{Hasil.}

Konsolidasi dengan tokoh masyarakat dan kader dimulai pada bulan Juni 2020. Kemudian dilanjutkan dengan persiapan alat dan modul pelatihan. Pelaksanaan pelatihan kader terlaksana 2 kali pada tanggal 5 Juli 2020 dan 8 Agustus 2020, diikuti oleh sebanyak 9 kader pada Posyandu Tempuyung dan 8 kader pada Posyandu Puspa Mekar dibekali pengetahuan konsep dasar stunting, cara memasang dan validasi alat, cara melakukan pengukuran Panjang/tinggi badan dan interpretasi hasil pengukuran 
dengan tepat. Media yang digunakan adalah modul pelatihan dan microtoise untuk pengukuran tinggi badan pada anak berumur $>24$ bulan serta infantometer untuk pengukuran Panjang badan pada anak berumur $\leq 24$ bulan. Stunting menggunakan modul yang sudah disiapkan. Masing-masing Posyandu juga diberikan infantometer karena selama ini pengukuran panjang badan masih dilakukan dengan metline atau alat pengukur panjang badan tanpa statis kaki sehingga hasil kurang valid.

Pelaksanaan monitoring dan evaluasi dilaksanakan pada bulan Agustus 2020 oleh tim dengan cara mendampingi kader saat pemeriksaan panjang/tinggi badan secara door to door ke rumah balita dikarenakan pelaksanaan posyandu belum berjalan sampai bulan Agustus karena kebijakan PSBB. Hasil monitoring menunjukkan peningkatan pengetahuan dan praktik kader dalam pelaksanaan pengukuran panjang badan dan tinggi badan anak.

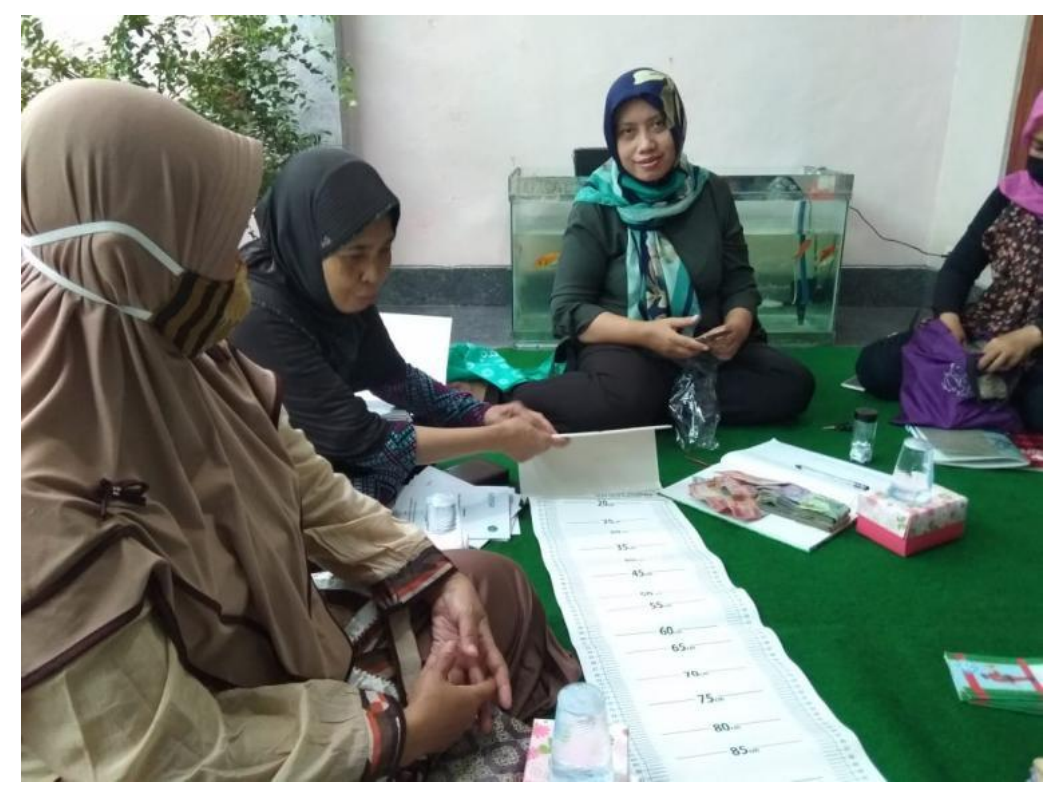

Gambar 1. Dokumentasi Pelatihan Kader Penggunaan Infantometer.

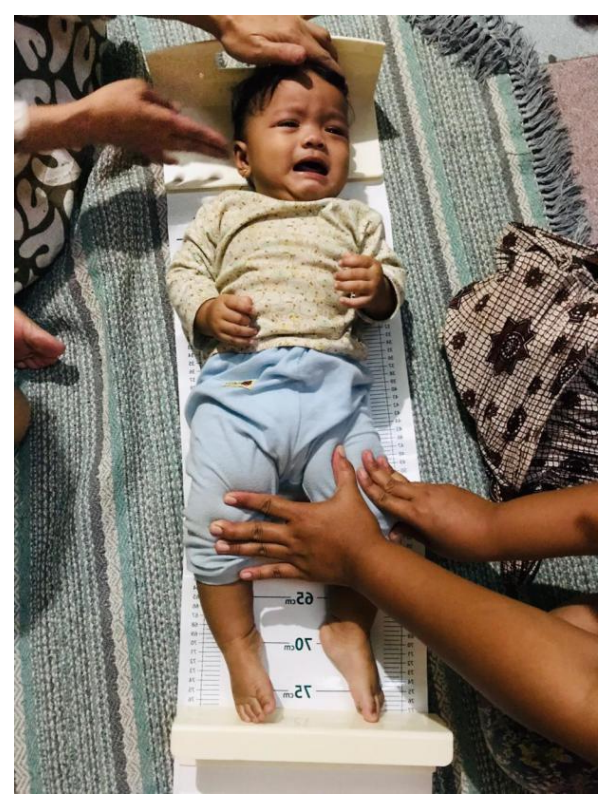

Gambar 2. Dokumentasi monitoring kegiatan pemeriksaan panjang badan oleh kader kesehatan melalui kegiatan posyandu secara door to door. 


\subsection{Pembahasan.}

Pengukuran tinggi badan merupakan suatu proses yang dapat dikatakan mudah tetapi juga sulit. Kekurangtelitian dalam step pengukuran dapat berpengaruh terhadap valid atau tidaknya data yang diperoleh. Bahkan terkadang membutuhkan trik tertentu yang akan diperoleh kader setelah latihan ataupun melakukan pengukuran berulang kali[14].

Selama ini pengukuran panjang badan dilakukan oleh satu orang saja, sehingga posisi bayi bisa saja berubah apalagi ketika anak rewel atau menangis dan mengakibatkan hasil tidak valid. Semestinya pengukuran dilakukan oleh 2 orang seperti gambar 3.

Prosedur pemeriksaan pengukuran Panjang badan pada anak $\leq 24$ bulan adalah:

a. Pengukuran dilakukan oleh 2 orang.

b. Bayi dibaringkan telentang pada alas yang datar, lepas topi dan dan kaos kaki

c. Posisikan kepala bayi menempel pada pembatas angka

d. Petugas 1 : memastikan kepala bayi menempel pada pembatas kepala/ angka 0 dengan cara kedua tangan memegang kepala bayi

e. Petugas 2: menekuk lutut bayi dengan tangan kiri supaya tetap lurus, dan tangan kanan menekuk batas kaki/statis kaki ke telapak kaki.

f. Petugas 2 membaca angka di tepi diluar pengukur.

g. Apabila anak berumur 0 - 24 bulan diukur dengan cara berdiri, maka hasil pengukurannya dikoreksi dengan menambahkan $0.7 \mathrm{~cm}$.

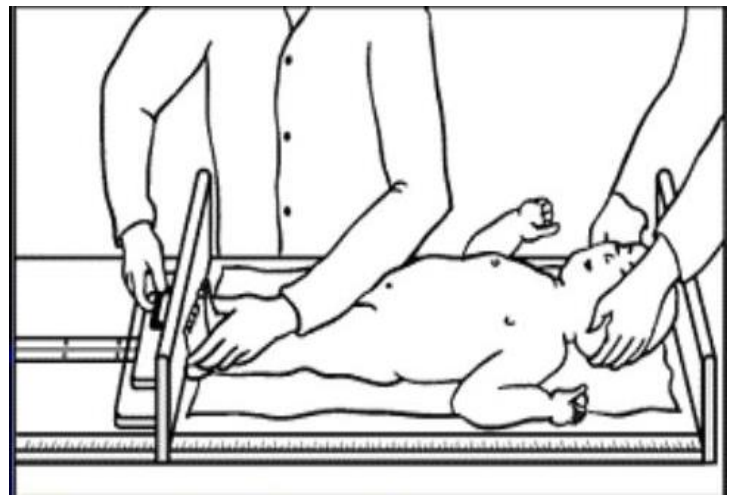

Gambar 3. Pengukuran panjang badan yang tepat [15]

Kesalahan dalam pengukuran tinggi badan yang pertama adalah kesalahan dalam pemasangan microtoise. Saat divalidasi oleh tim, microtoise yang terpasang tidak menunjukkan angka nol pada jendela baca saat ditarik ke bawah. Seharusnya pemasangan microtoise adalah sebagai berikut: 


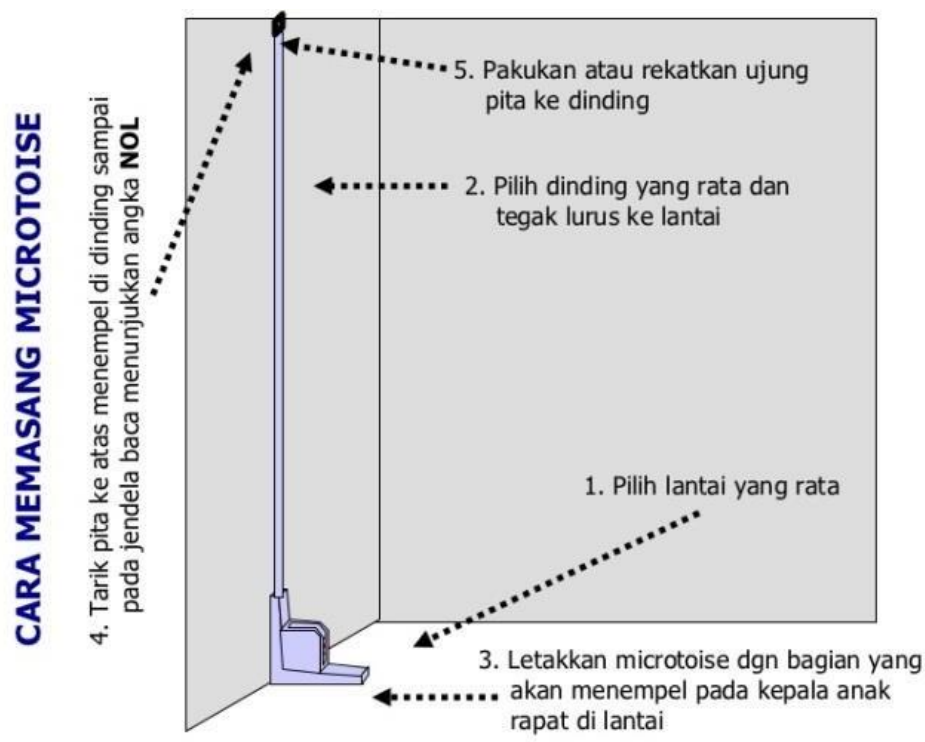

Gambar 4. Cara memasang microtoise.

Selain itu, kader belum tepat dalam memposisikan anak seperti contoh pengukuran pada anak perempuan tidak melepas ikat rambut, posisi bahu, bokong dan tumit tidak menyentuh pengukur atau tembok dan tumit tidak dalam kondisi rapat/ saling menempel. Selain itu terdapat kesalahan saat membaca hasil tidak karena mata tidak sejajar dengan jendela baca. Contoh kesalahan yang sering terjadi nampak pada gambar 5. Kondisi yang demikian akan berpengaruh terhadap akurasi data yang diperoleh.

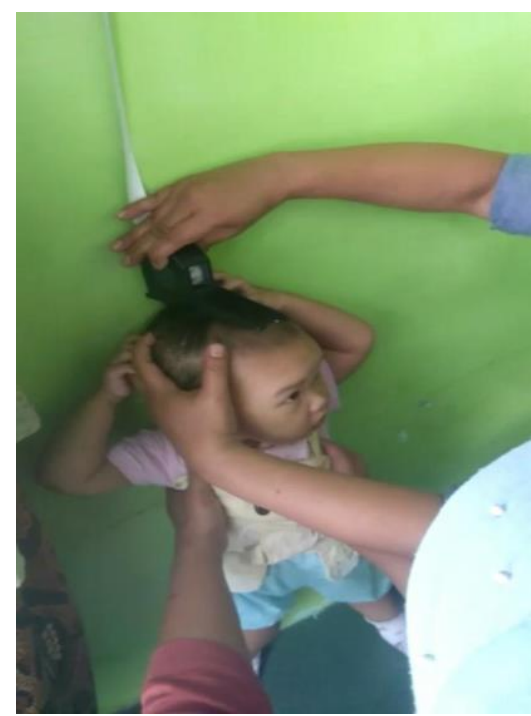

Gambar 5. pemosisian anak saat pengukuran tinggi badan kurang tepat.

Prosedur pemeriksaan tinggi badan yang benar adalah:

a. Anak berdiri tegak menghadap ke depan tanpa mengenakan alas kaki (sandal, sepatu atau kaos kaki).

b. Posisikan bagian punggung, pantat dan tumit menempel pada tiang pengukur (kedua kaki rapat dengan tumit saling menempel).

c. Menurunkan batas atas pengukur sampai menempel di puncak kepala/ ubun-ubun anak.

d. Membaca angka pada batas atas kepala dengan posisi mata pengukur sejajar dengan skala alat, tidak dari samping/ atas/ atau bawah. 
e. Apabila umur anak diatas 24 bulan dan diukur dengan cara terlentang, maka hasil pengukurannya dikoreksi dengan mengurangkan $0.7 \mathrm{~cm}$.

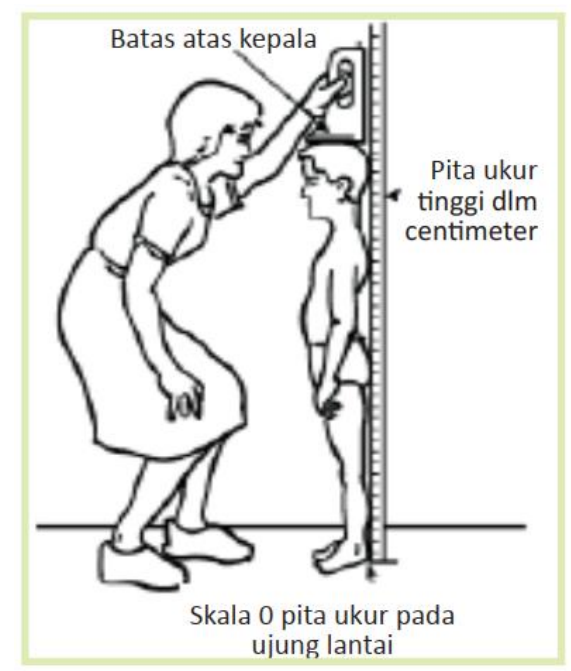

Gambar 6. Pengukuran tinggi badan yang tepat[15]

Kegiatan ini merupakan penerapan model komunikasi S-O-R: (Stimulus - Organisme- Respon). Pada kegiatan ini stimulus yang diberikan berupa pelatihan yang diterima oleh kader dengan baik dibuktikan dengan adanya perhatian dan usaha untuk memahami materi pelatihan dan selanjutnya memperbaiki kesalahan yang pernah dilakukan saat sebelum pelatihan dan mempraktikkan dengan baik materi yang didapatkan saat pelatihan[16]. Sumber informasi Kesehatan yang utama pada masyarakat adalah kader[6].

Untuk itu, perlunya pengetahuan yang adekuat dimiliki oleh para kader kesehatan untuk dapat memberikan edukasi kepada masyarakat dalam upaya pencegahan stunting. Peran tenaga Kesehatan tidak dapat lepas dari hal ini, sehingga perlu dibangun sinergi yang kuat antara kader dan tenaga Kesehatan supaya dapat menjadi perpanjangan tangan dalam upaya pengendalian stunting. Jika masyarakat memiliki pengetahuan dan kesadaran yang baik terhadap stunting maka dampak antargenerasi pada stunting ini bisa diputus. Karena orang tua yang stunting besar kemungkinan akan melahirkan anak yang stunting. Dengan demikian kualitas keluarga akan terancam dan terus menjadi lingkaran masalah sulit untuk diputus[6].

\section{SIMPULAN}

Kegiatan penguatan pengetahuan dan keterampilan kader kesehatan dalam pemantauan pertumbuhan anak khususnya pengukuran Panjang/tinggi badan sangat diperlukan agar hasil pemeriksaan akurat. Dengan demikian data pengukuran yang dilaporkan kader kesehatan ke posyandu menjadi data akurat yang akan diolah menjadi data prevalensi stunting di Indonesia. Perlu adanya sinergi antara posyandu dengan puskesmas setempat untuk peningkatan pengetahuan kader Kesehatan tentang stunting dan monitoring evaluasi pelaksanaan pemeriksaan Panjang/tinggi badan di posyandu.

\section{UCAPAN TERIMAKASIH}

Terima Kasih kepada Universitas 'Aisyiyah Yogyakarta melalui LPPM yang telah membiayai kegiatan pengabdian masyarakat ini. Terima Kasih kepada tokoh masyarakat dan kader kesehatan di Karangkajen, Mergangsan, Kota Yogyakarta, DIY yang sudah mengizinkan dan berpartisipasi dengan baik dalam kegiatan pengabdian masyarakat ini. 


\section{REFERENSI}

[1] Kementerian Perencanaan dan Pembangunan Nasional, Peta Jalan SDGs Indonesia Menuju 2030. 2019.

[2] Kementerian Kesehatan, "Sekretariat Kabinet Republik Indonesia _ Menko PMK_Target Angka 'Stunting' di Bawah 680 Ribu Per Tahun- Sekretariat Kabinet Republik Indonesia.” 2020, [Online]. Available: https://setkab.go.id/menko-pmk-target-angka-stunting-di-bawah-680-ribuper-tahun/\#: :text=Menteri Koordinator Bidang Pembangunan Manusia,bawah 680 ribu per tahun.

[3] Kementerian Kesehatan, "Kementerian kesehatan fokus pada pencegahan stunting," 2019, no. November 2019. pp. 1-9, 2019.

[4] Tim Nasional Percepatan Penanggulangan Kemiskinan, "100 Kabupaten/Kota Prioritas untuk Intervensi Anak Kerdil (Stunting)," pp. 1-27, 2017.

[5] A. Rahayu, S. Km, and M. Ph, Buku Ajar Gizi 1000 Hari Pertama Kehidupan. 2018.

[6] Direktorat Promosi \& Pemberdayaan Masyarakat, "Strategi Komunikasi Perubahan Perilaku," 2018.

[7] Kementerian Kesehatan Republik Indonesia, "Perangi Stunting dengan Jaga Periode Usia Emas Indonesia.” 2019.

[8] Kementrian Kesehatan RI, Pedoman Umum Pengelolaan Posyandu. Kementrian Kesehatan RI, 2011.

[9] I. S. Fitriani and R. R. Oktobriariani, "Stimulasi, Deteksi dan Intervensi Dini Orang Tua terhadap Pencegahan Penyimpangan Pertumbuhan dan Perkembangan Anak Balita," Indones. J. Heal. Sci., vol. 1, no. 1, p. 1, 2017, doi: 10.24269/ijhs.v1i1.383.

[10] K. K. R. Biro Komunikasi dan Pelayanan Masyarakat, "Posyandu dan Puskesmas Garda Depan Pengendalian Stunting," 29 Januari 2020. 2020, [Online]. Available: https://www.kemkes.go.id/article/view/20013000002/posyandu-dan-puskesmas-garda-depanpengendalian-stunting.html.

[11] S. Wuwuh, S. Rahayu, and K. Wijayanti, "Pengaruh Pendampingan Kader Pada Ibu Hamil Terhadap Kepatuhan Minum Tablet Fe," J. Ilm. Bidan, vol. 1, no. 3, pp. 1-6, 2016.

[12] R. Hardiyanti, I. Jus'at, and D. Angkasa, "A relationship from long working to cadre, knowledge, education, training with precision and accuracy of weighing result by cadre at Integrated Health Post," Action Aceh Nutr. J., vol. 3, no. 1, p. 74, 2018, doi: 10.30867/action.v3i1.

[13] Susilowati, "Pengukuran Status Gizi dengan Antropometri Gizi," pp. 1-76, 2008.

[14] N. Fuada, S. Salimar, and A. Irawati, "Kemampuan Kader Posyandu Dalam Melakukan Pengukuran Panjang/Tinggi Badan Balita," J. Ekol. Kesehat., vol. 13, no. 3 Sep, pp. 229-239239, 2014, doi: 10.22435/jek.v13i3Sep.5118.229-239.

[15] Kementrian Kesehatan RI, Pedoman pelaksanaan stimulasi, deteksi, dan intervensi tumbuh kembang anak. Jakarta: Kementrian Kesehatan RI, 2016.

[16] Metty and Inayah, "Pelatihan Pengukuran Antropometri Dan Sosialisasi Pedoman Gizi Seimbang Pada Kader Posyandu Johar XII Rusun Jogoyudan, Jetis, Kota Yogyakarta," J. Pengabdi. Dharma Bakti, vol. 1, no. 1, pp. 39-45, 2018. 